\title{
Co-operation and life during wartime
}

Following Horace Plunkett's departure from the Department of Agriculture and Technical Instruction (DATI) and until the end of the First World War, the Irish co-operative movement experienced a series of trials that threatened its programme for rural improvement. The Irish Agricultural Organisation Society (IAOS) contended with hostile agricultural policymakers and nationalist politicians, but the organisation also faced new challenges presented by the outbreak of the Great War in August 1914 and the demands of a wartime economy. At the end of the war the IAOS assessed where it stood at the end of that experience:

The stability of the movement for which the IAOS stands has been subjected to a crucial test during the last five years. Its steady growth and remarkably rapid development in new directions - some of a far more ambitious character than any previously undertaken by the organised farmers - afford yet another proof of the superiority of co-operative organisation under conditions of stress. The societies have not only held together, but have also improved their buildings and equipment as well as their business methods, and have increased their output to an extent greater than during any other period. ${ }^{1}$

Throughout the war the IAOS acted as a centre of stability for tens of thousands of farmers and emerged with a newfound sense of confidence and purpose despite the trying circumstances it met during those years. However, at the same time Ireland emerged from the global conflict bitterly divided and on the precipice of violence and revolt.

When the co-operative movement moved into the twentieth century's second decade its prospects seemed mixed. The IAOS had established the co-operative society as a familiar institution throughout the countryside that placed the means of dairy production, distribution of goods to market and access to limited finance under the control of farmers. The IAOS also showed it aptitude to profoundly shape the agrarian economy through its displacement of the Co-operative Wholesale Society (CWS) as a major player in the dairy industry. Yet the decade also heralded serious problems. The immediate challenge that beset the IAOS concerned its relationship with the DATI. The change in departmental leadership meant a 
reorientation in Irish agricultural policy and a reduced role for co-operative voices in the formulation of agricultural policymaking. In peacetime, the IAOS and DATI sat uncomfortably alongside one another. The outbreak of the Great War compounded an already problematic relationship at a time when the Irish farmer's ability to meet the demands made by a wartime economy mattered more than ever.

The Great War drastically changed Ireland's political relationship with the rest of the United Kingdom. One major reason stemmed from developments that resulted from the Easter Rising in April 1916. This armed rebellion against British rule by a radical minority of Irish nationalists in Dublin changed the contours of the Irish Question and led to increased sympathy for the separatist cause. ${ }^{2}$ The Sinn Féin party, founded in 1905, experienced a rapid growth in support after the armed uprising in Dublin. Sinn Féin benefited from an ability to position themselves as the heirs to the rebellion's legacy and as their demands for an Irish Republic gathered momentum they displaced the Irish Parliamentary Party (IPP) as the mainstream representatives of nationalist Ireland at the 1918 General Election. ${ }^{3}$ Sinn Féin's electoral performance heralded the arrival of a new, separatist force in Irish nationalist politics that hastened a conflict between Irish Republicanism and the British state after the war. However, economic changes in Ireland following the war also played a part in changing the colour of nationalist opinion in Ireland. This chapter focuses on the ways in which this new generation of 'vivid faces', to use R.F. Foster's soubriquet for the young nationalists of the early twentieth century, used economic arguments and ideas associated with the cooperative movement to define a nationalist developmentalist strategy. Æ's economic ideas proved particularly influential in this intellectual shift.

During the war, the issue of a secure food supply was one of the political priorities facing the British government as it looked to secure military victory. Ireland emerged as an important part of the British war economy. As a country with a large agricultural sector, it was well-positioned to help ensure Great Britain received its required foodstuffs despite the German navy's efforts to disrupt imports. The Great War proved to be a relatively plentiful time for Irish farmers as the state guaranteed the prices of agricultural produce. Over the course of the conflict Irish agricultural produce doubled in value which, despite the rise in wage and price inflation, represented a bonanza for Irish farmers. ${ }^{4}$ Patrick Kavanagh colourfully recalled the generous impact of the wartime price guarantees on the farmers' pocket. Kavanagh, who grew up in rural Monaghan during the war, recalled boyhood scenes whereby 'every Sunday coming home from Mass I heard all around me: "It's a great war for the farmer. Cattle up four pounds a head." "The German's a good soldier. Up the German." 5

Certainly the notion that 'the war brought floods of money into Ireland' was widely held and an impression lingered that 'agriculture had a golden time, and all the profits of agriculture went to the occupiers of the land'. ${ }^{6}$ The distribution 
of profits reflected the amount of land a farmer held, with larger farmers drawing a greater benefit than smaller farmers and labourers. Agricultural prices were three times higher in 1920 than in 1913 and farmers with larger landholdings made more money, owing to their ability to exploit the prices paid for crops. However, the picture of wartime economic prosperity painted by Kavanagh sits uneasily alongside the violent rejection of the British state that occurred in the war's immediate aftermath. This chapter attempts to understand how this discontent partly arrived out of the economic sphere by examining how the war effected the co-operative movement's position. An important factor in the promotion of disaffection came from Æ's intellectual positioning of co-operators in an increasingly hostile state system. He shaped the perceptions of nationalists that the war allowed Britain to impose a tyrannical economic arrangement on the Irish people.

The outbreak of the First World War overturned the prevalent political circumstances across Britain and Ireland. The domestic political context changed dramatically. The outbreak of a nationalist rebellion in Dublin during Easter 1916 shifted the tectonics of the 'Irish Question'. Members of the secretive underground organisation, the Irish Republican Brotherhood, alongside the socialist Irish Citizen's Army, directed a city-wide armed uprising against British rule. On 24 April 1916, its leaders announced the existence of an independent Irish Republic and the very public arrival of a nationalist opinion much advanced from the familiar demands for Home Rule. Suppressed within a week, and its leaders executed, the legacy of the Easter Rising exerted a radical change in mainstream nationalist opinion. F.S.L. Lyons famously described the Rising's principal political achievement as 'the point of departure ... for all subsequent Irish history'. ${ }^{8}$ One IAOS leader was directly affected by the events. Robert Anderson, whose experience of those years mirrored 'that of many thousands of fathers', lost his son Alan on the Western Front in 1914. Anderson was wounded in the Rising as he fought as a member in the army's reserve volunteer force known as the 'Gorgeous Wrecks' due to their uniform's inscription of Georgius Rex.'

However, everyday experiences in rural communities remained largely unaffected in the immediate aftermath of the rebellion challenging perceptions of 1916 as a moment of sudden and radical change. The consequences of the rebellion took time to filter down to the rural community. When they did the effects would be brutal and violent, but in the summer of 1916 farmers remained more concerned about their ability to produce items such as butter, milk and livestock as they aimed to sell these goods at the best price upon the market.

The IAOS remained an institution in demand among members and its continued work amid moments of political change implied an element of continuity within the state of Ireland. Increased instances of state intervention that drastically shaped everyday life across Britain and Ireland dramatically affected the lives of rural people. Farming regulations, control orders and the repercussions of an economic blockade intensified demand for Irish foodstuffs across the United 
Kingdom. However, such state interventions needed to pass through existing institutions. In Ireland this meant the demands placed on agriculture by an increasingly centralised government still occurred via farmers' businesses and institutions that predated the shift to a wartime economy. Co-operatives were central to the shift to a wartime economy. Fran Brearton has argued the war exerted a different impact upon Ireland, from that of England. In England, the war symbolised a break with the past and the destruction of pre-war institutions, but in Ireland the war 'played a part in a history whose main themes and "institutions" existed long before the Great War and continued long after it was over'. ${ }^{10}$ The wartime experience of the co-operative movement supports this claim. The co-operative movement helped farmers to meet new expectations through its co-ordination of expertise and resources. Co-operators helped to ensure the necessary output of food and that their members shared in the rewards and achieved those things despite the fact that the DATI continued to marginalise the IAOS in official agrarian policy. Lionel Smith-Gordon, who worked in the IAOS's headquarters at Plunkett House, noted in 1917 that, 'the IAOS has been swallowed up in the vortex of war and is playing its important part in comparative obscurity'. ${ }^{11}$ This obscurity defined its relationship with the state, but its work did not go unheeded by those who relied upon the IAOS.

\section{The movement on trial}

The outbreak of the First World War caused a seismic change within Irish society. Political debates around Home Rule became side-lined as the government intensified the war effort. In 1914, the IAOS executive issued a patriotic rallying cry which emphasised that the economic challenges of war could only be met with the aid of their movement:

Without the co-operative movement, the scarcity of labour, consequent on the war, would probably result in a still further diminution of the acreage under tillage; with it the shortage of labour can be to a great extent counterbalanced by the more general use of labour saving machinery. The movement is on its trial [emphasis added]. ${ }^{12}$

The challenge for Irish co-operators lay in the execution of their duties at a moment of international crisis. Horace Plunkett 'had from the first seen that food supplies would be one of the keys to victory, and he had been anxious for the IAOS to use its powers to increase food production in Ireland'. ${ }^{13}$ In a presidential address to the IAOS in October 1915 Plunkett pointed out that in normal circumstances 'the man in the street, as the final authority in the mind of the politician is not inaptly called, does not bother his head about agriculture'. As long as this individual and the intelligent housewife can buy their 
groceries at a moderate price they are satisfied. However, war transformed this situation and

the man in the street has been alarmed by the new conditions of naval warfare. As he walks along with his head erect, a sort of periscope to his stomach, he sees on the newspaper posters the exploits of the submarine and, in the shop window, the prices of his food mounting up. It dawns upon him that those who devote themselves to growing food within the safe borders of these islands are fulfilling a useful purpose; and so the neglected industry comes in for an unusual share of public attention. ${ }^{14}$

Plunkett saw that the war represented a new test of co-operative principles. The war offered a test 'of the character and a capacity of the rural democracy' built by co-operators up to that date. ${ }^{15}$ Moreover, the role played by the IAOS in spreading technological innovations through Ireland showed one important way it prepared the country to meet wartime demands.

The outbreak of the war led to a rapid increase in the output of agricultural produce in the British economy. ${ }^{16}$ Food supply formed a major concern of British governance in wartime and Irish agriculture remained a central plank to Britain's economic performance. The IAOS pleaded with the DATI to co-ordinate their work for the sake of the war effort and to put 'an end to all friction between the official and voluntary agencies working for agricultural development in Ireland and insuring their harmonious co-operation' ${ }^{17}$ The DATI and IAOS initially presented a united front as they appealed to farmers' patriotism to utilise their resources to the greatest national advantage. The IAOS and DATI issued complementary public notices to farmers to conserve food and offered instructions on issues such as vegetable cultivation, crop rotation and directions to maximise production. J.R. Campbell, Assistant Secretary for Agriculture at the DATI, urged farmers to concentrate upon tillage farming and increased efforts to extend dairying in Ireland to cover winter months. ${ }^{18}$

The IAOS's ability to provide targeted support proved to be of immense value for farmers. The co-operative movement provided assistance to Irish farmers during the war as organisers helped to adapt the economic functions of societies where necessary. This mirrored similar experiences other countries. For example, agricultural co-operatives in Russia helped peasants meet new demands as leading co-operators saw the war 'as an opportunity to create a more systematic programme of agronomic research and assistance'. ${ }^{19}$ As early as 1911 , $Æ$ argued that the co-operative movement offered the means through which farmers could respond to pressures in a nimble fashion: 'the power to continuously adjust production to the needs of the market is one of the greatest advantages of association among farmers..$^{20} \rightleftarrows$ had not envisaged anything of the order entailed by a shift to a war economy, but adaptability to the needs of consumers and producers 
would be a hallmark of co-operative utility during wartime. For example, the IAOS disseminated information to large sections of the population. In August 1914 the IAOS issued every co-operative society with a supply of leaflets that offered farmers instructions 'as to how supplies of human and animal food may best be increased and conserved'. ${ }^{21}$ The manager of Abbeydorney Co-operative Dairy Society requested copies of this pamphlet to share with its members. The IAOS immediately sent 200 copies of its 'War and the Food Supplies' pamphlet to Abbeydorney to advise the local farmers. ${ }^{22}$ The IAOS maintained contact with a large number of farmers and remained aware of their requirements and anxieties.

In a sign that past grievances might be placed to one side, the DATI invited Horace Plunkett on to a departmental committee that considered the steps needed to increase Irish food production. In particular, the committee wanted to reverse the trend that saw the number of acres under tillage decrease in previous years and effect an increase in the amount of grain produced for consumption. Among its recommendations was a commitment to increase the area of land under tillage with an agreement to introduce some price controls such as a one-year regulation to set a minimum price for wheat and oats. Other commitments included new powers for the DATI to prevent the slaughter of breeding livestock and loans offered to farmers and fishermen to buy implements and machinery. ${ }^{23}$ Alone among the committee members, Plunkett dissented from the majority's findings and refused to support the report. He grew frustrated about the lack of precise detail around such recommendations and worried about the absence of any proposal to utilise the existing co-operative network to achieve these aims. He proposed an amendment to the report which argued that any rise in food production depended upon 'at least as much voluntary effort as upon governmental action'. Plunkett argued that the IAOS had proved in the past that it could stimulate an increased level of food production as exemplified by the uptake of modern dairying in earlier years. 'Where farmers have used their co-operative organisation for the purpose of enabling them to adopt a more intense cultivation', Plunkett proposed in a resolution to the Departmental Committee, 'a remarkable increase in food production has already taken place'. He cited a number of expert witnesses to support this point including Thomas Wibberley, an agricultural instructor based at Queen's University, Belfast, and expert on continuous cropping. ${ }^{24}$ Plunkett's amendment lost by eleven votes to four and the attempt to gain official approval of the IAOS's work failed. Instead, he submitted his Minority Report, in which he argued that an increase in food production required the adoption of the co-operative method. In submitting this report, Plunkett claimed to 'speak for tens of thousands of farmers, whose wishes and opinions I am in a position to know'. ${ }^{25}$ Plunkett's minority report remained unheeded by the DATI.

The failure of the IAOS and DATI to reconcile differences and work harmoniously represented a lost opportunity. The IAOS Report for 1915 interpreted the 
rejection of Plunkett's amendment as an act of 'official discouragement' to cooperative work. The Department's attitude betrayed a determination to deal with farmers on an individual basis rather than through corporate entities like the co-operative society. A view that the war provided a cover for economic opponents to undermine the IAOS peppered the movement's discourse over the next few years. As the report summarised, 'the knowledge that the Department ... is hostile to the IAOS must obviously have a disturbing, if not a paralysing effect upon the scattered working farmers throughout the country'.

In stark contrast to continental farmers the war showed up how the efforts of governmental and voluntary agencies lacked 'efficient economical co-ordination'. ${ }^{26}$ As the workload of co-operative organisers increased due to the new stresses caused by wartime conditions the absence of state support grew apparent. The number of demands made on an organiser's time meant attendance to co-operative societies' requests often needed to wait for weeks. In an indication of the frustrations borne out of these demands Anderson confided to Charles Riddall that he abhorred the habit of societies to organise meetings for Sundays because 'quite apart from the indecency of it our organisers ought to have a rest at the week end'. ${ }^{27}$ Notably, a failure to promote a standardised approach to increased levels of food production across the whole farming population harmed Irish producers in the longer term and contributed to the loss of goodwill from customers after the war. ${ }^{28}$

The IAOS expanded its knowledge base to enable societies to adapt to wartime conditions. The Co-operative Reference Library proved useful in this matter. The idea for a co-operative research centre came out of Horace Plunkett's annual visits to the United States. Plunkett established a fruitful working relationship with Charles McCarthy in Madison, Wisconsin. McCarthy, a young Irish-American social scientist and policy researcher, founded the first legislative reference library in the United States and saw the role of good policymaking as something that needed to be informed by thorough research and an understanding of the results provided by international experimentation. ${ }^{29}$ Inspired by McCarthy, Plunkett conceived of a Country Life Institute to stimulate new innovations in Irish rural development. Plunkett anticipated that such an 'Irish-American contribution to rural progress' would aim

to advance the well-being of the large and scattered agricultural population by bringing together information as to the progress of rural communities, by encouraging the scientific study and investigation of the conditions which contribute to their social and economic advancement, and by spreading knowledge and stimulating public opinion on the vital importance of a strong farming and rural community to the maintenance of the national life as a whole. ${ }^{30}$

Although several years elapsed before such an institution started up, Plunkett founded the Co-operative Reference Library following the receipt of a Carnegie Trust grant in 1914. The library aimed to become an international centre 'of 
information for practical workers and others interested in the development of agricultural and industrial co-operation'.

The war interrupted this cosmopolitan work, but within Ireland the library published wartime studies, which investigated issues such as food supplies, the establishment of co-operative bakeries, and hygienic concerns around urban milk supply. ${ }^{32}$ Between 1914 and 1918 the library's staff tried to synthesise as much international material as possible to inform future directions in co-operative farming. Francis Cruise O'Brien's work on co-operative mills and bakeries provided co-operators with information on how to extend productive capacities. Obtaining the required information proved difficult. The German co-operative bakeries O'Brien wished to examine proved inaccessible. However, the international contacts made through the Co-operative Reference Library meant he had access to a wide range of information.

O'Brien maintained a successful correspondence during the war with a milling society in southern France, which meant he 'obtained much valuable information, and from other sources I have been put into possession of important facts not hitherto published'. ${ }^{33}$ Drawing upon such research, the IAOS encouraged the establishment of co-operative milling facilities, in order to increase the levels of food production and to increase and diversify the productive capacities of cooperative societies. Lionel Smith-Gordon, employed as the co-operative librarian, argued in 1914 that many of the economic difficulties instigated by the war 'could be solved by putting business on a co-operative basis'. The 'clash of interests' which caused friction during periods of emergency 'cannot arise when the interests of the retailing agency are identical with those of the consuming public'. A complete co-operative arrangement of the economy that encompassed production, distribution and retail offered one response to the demands placed on the population at the start of the war and suggested a hope that 'the present time is one which opens up tremendous possibilities for the co-operative movement'. ${ }^{34}$

Co-operative societies shored up their position in the economy through a diversification of their operations, which required a mighty co-ordinated effort from the IAOS. Robert Anderson recalled that 'Co-operation was called on to put forth efforts in directions as novel to its staff as they were to the reluctant farmers to whom they had to make appeal'. ${ }^{35}$ Co-operative creameries proved ready to adapt to new demands, which in turn ensured members could share in any profits that derive from new methods of production. Co-operative creameries rapidly diversified in order to meet economic demands, and simultaneously expanded their utility to members. As early as 1915, 248 out of 344 co-operative creameries engaged in the trade of goods other than butter. This 'agricultural trade' encompassed a wide range of services, including the sale of agricultural inputs and the provision of credit. ${ }^{36}$

The members of Drumcliffe Co-operative Society decided to establish their own new co-operative mill in April 1916 after increased prices charged for bread 
led farmers to view such a move as beneficial. The establishment of such societies also incentivised the increase in tillage farming desired by the government. Josslyn Gore-Booth outlined in a speech to members that the committee of the society realised that it was the want of a mill with up-to-date machinery within reasonable distance which more than anything else was keeping the people from growing more grain'. ${ }^{37}$ The establishment of new modes of production at the co-operative society showed how co-operative committees could nudge farmers towards new working practices that proved financially beneficial.

The IAOS played an important part in helping societies to instigate reforms in response to changed economic circumstances and it 'was called on to organise societies for milling, for curing bacon, for owning expensive machinery in common, to be lent out to members' ${ }^{38}$ For example, in January 1915 Abbeydorney Cooperative Society in County Kerry had 150 members, which included members of their auxiliary at Kilflynn. A hundred of these members directly supplied the central creamery and the remainder supplied the auxiliary. Organiser John O'Leary visited Abbeydorney and reported back to Robert Anderson on a wellmanaged society. All sewage and waste water was disposed of in a satisfactory manner; the grounds, building and machinery were maintained in good order; the quality of the milk supplied by members was 'clean and sweet' with all sour milk rejected; the creamery supplied loans to members on the condition that they continued to supply milk; and 'the books were examined compared and found in order'. ${ }^{39}$ Later that month, Abbeydorney's manager wrote to Anderson to inform him that the members established flour mills in order to engage in bread production. $^{40}$

For the year 1915-16, the society also benefited from a significant increase in the amount of milk supplied, from 109,180 gallons in July 1915 to 129,245 gallons in July 1916. This expanded milk supply came from an increased number of suppliers to the creamery who refused to subscribe as members with the membership stuck at 150 members; but an increase in the number of suppliers reached $190 .{ }^{41}$ The war highlighted a recurrent free rider problem that dogged local co-operative societies. Co-operatives tended to rely on a committed core of co-operative farmers for their success, which in turn brought a wider economic benefit across the district in the guise of cheaper implements and higher prices paid for milk. A refusal to turn away milk supplied by non-members helped societies increase output in the short term. In the longer term this practice failed to convince non-member suppliers to join the co-operative, which meant a section of farmers remained free to use a rival creamery if they calculated the move paid better. Such arrangements exposed the limitations of the IAOS to convert the whole rural population to the benefits of co-operation.

Charles Riddall arrived at Abbeydorney on 6 August 1916 to address a meeting of local non-member suppliers to convince them to become full members. Riddall's timing proved unfortunate. He arrived at the town to find the meeting cancelled 
due to two funerals taking place in the area. ${ }^{42}$ Anderson wrote to Riddall and expressed his annoyance with the priority granted to traditional customs by country people over what he regarded as the higher priority of the administration of the local society:

It is most disappointing to have meetings rendered abortive in this way. The country people do not seem to value time in the slightest degree and they will spend a whole day over a funeral or rather over the part of the ceremony which has nothing to do with the internment and attend to nothing else. ${ }^{43}$

Whether the IAOS head office liked it or not, marking the passing of the dead still demanded people's attention.

Food production methods tailored to meet the changing wartime dietary needs of the British population required co-operative societies to erect new facilities and purchase new machinery. The purchase of new plant facilities came under the strict regulation of the new Minister of Munitions established after the severe shortage in shell production during 1915 caused a panic in the Liberal Government. As IAOS Secretary, Robert Anderson made representations to the minister on behalf of individual societies. Anderson presented the case for co-operative societies to be granted permission to purchase new engines and plant material in order 'to enable the Creamery to continue its business of manufacturing butter for which there is at present a special urgency in this country. ${ }^{44}$ Anderson highlighted in an article written to promote the achievements of the IAOS how new co-operative societies designed to purchase expensive machines that members could then hire emerged during the war. This placed 'small farmers in a position to command labour-saving implements which they could never have purchased individually' and meant some of 'the poorest neighbourhoods have increased their tillage by nearly a hundred per cent in a year as a direct result of this development'. ${ }^{4}$

Creameries also shifted from butter to cheese production in the final months of the war. They offered high prices for cheese as a way to meet the demand for protein required in British diets. Irish cheese production expanded hugely from 10,000 tons produced for export in 1914 to 286,000 tons by $1919 .{ }^{46}$ An advertisement featured in the Irish Homestead framed the switch from butter to cheese production within a discourse that emphasised 'Economy, patriotism, health', three virtues that 'all call for a greater use of this valuable food'. ${ }^{47}$ The IAOS's support to local societies once again proved to be a crucial factor in the establishment of new cheese-making facilities, with creamery inspections designed to aid the smooth and rapid transition to the new manufacturing process. Managers requested the IAOS's aid in order to equip creameries with the required machinery for cheese-making. Inter-creamery competition also incentivised the adoption of cheese-making across Munster. The manager at Newtownsandes Co-operative Society, Thomas de Lacy, decided to switch from butter to cheese production facilities when he noticed that other nearby creameries had already decided to 
do so. He wrote to Charles Riddall at Dublin to explain that he arrived at the decision as the society needed to keep up with other co-operatives because 'if they can do this we must follow suit or go under'. ${ }^{48}$

James Fant contributed to this infrastructural shift more than any other. Fant worked for the IAOS as a creamery expert but possessed special expertise as an engineer and architect. By 1914 Fant already proved his worth to the movement as he assisted societies when they required information about the type of plant machinery they required such as creamery separators, refrigeration devices and pasteurising equipment. In James Fant, the movement possessed a 'special creamery organiser with expert qualifications ... [whose] services are always in demand, and ... the IAOS could profitably employ at least four such organisers if it had the funds wherewith to do so. ${ }^{49}$

Fant often supplied co-operative societies with engineering drawings and plans for their use in the upgrade and improvement of their buildings and capabilities. He offered help when societies had to decide what dairy technology they needed, and visited societies across the country as required. ${ }^{50}$ At an IAOS Ulster District meeting held at Monaghan in February 1917, the region's co-operative movement celebrated its ongoing development during the war. Ballinode Co-operative Society represented a model of progress made by the movement as it boasted premises that 'has been remodelled and re-equipped, and there was a very considerable increase in supply during the year'. William de Vismes Kane, a leading member of the society singled out James Fant for praise, claiming that the people of Ballinode 'owed an eternal debt of gratitude' to the IAOS engineer for all the advice which 'enabled them to pull through a very great difficulty'. ${ }^{51}$

The shift towards new forms of production led the IAOS to celebrate their involvement in the Irish farmer's war record:

The most notable of the developments attributable to the war is the widespread adoption of cheese-making in Munster, and to a less extent other parts of Ireland. Few creameries in Munster that have failed to engage in it have been able to meet the stress of competition. ${ }^{52}$

The IAOS's organisers offered the requisite support to meet the government's demands to meet the nutritional needs of consumers. Nevertheless, cheese production proved to be a temporary feature of Irish creamery production due to changes in the post-war economy, but also due to the low quality of the produce. ${ }^{53}$ The demand for cheese was such that the state purchased any grade of produce for a guaranteed minimum price. As the war drew to a close the IAOS appealed to co-operative committees to 'examine their consciences' when it came to quality control of their cheeses. ${ }^{54}$ By the 1920 s creameries once again focused on the production of butter.

The IAOS's main purpose during the war was to assist local societies adapt to a wartime economy. For many farmers the local co-operative society helped 
Table 4.1 Co-operative societies, 1914-18

\begin{tabular}{lcc}
\hline Year & $\begin{array}{l}\text { No. of societies (creameries, } \\
\text { credit societies etc.) }\end{array}$ & Membership \\
\hline 1914 & 1,023 & 106,212 \\
1915 & 991 & 102,591 \\
1916 & 958 & 106,301 \\
1917 & 947 & 113,640 \\
1918 & 950 & 117,484 \\
\hline
\end{tabular}

Source: IAOS, Annual Reports, 1914-1918.

to mediate their experience of this boom in Irish agriculture. The work of IAOS employees such as James Fant and Robert Anderson helped the local co-operative committees repurpose their buildings to create a new economic infrastructure suited to the wartime economy and ensured farmers continued to supply the goods required. Local co-operative societies provided the capacity for farmers to engage in a wider range of economic activities and experiment in ways they could not achieve if they tried to act alone. To illustrate this point $Æ$ cited the example of a society in Kerry, which invested a $£ 2,000$ overdraft in new methods of production that benefited members, where

grain was bought and the mill worked to the utmost extent possible, with the result that members were able to get feeding stuffs for cattle and pigs, and there has been more prosperity in the district than at any time in its history. ${ }^{55}$

Fixed prices played an important part in this prosperity, but $Æ$ asserted that only the local co-operative society provided farmers with the tools and philosophy to attain their rightful share of available wealth.

By 1918, farmers understood that connection with a local co-operative society promoted their interests and improved their industry. Although the number of societies contracted slightly, the membership experienced a slight growth from 106,212 to 117,484 members (see table 4.1 ). One result of wartime prosperity saw co-operative societies increase their affiliation payments to the IAOS. Subscriptions jumped by 30 per cent between 1917 and 1918 in recognition of the assistance rendered by the organisation. ${ }^{56}$ However, there remained significant competition for milk supplies from a resilient private sector that ensured a number of milk suppliers remained impervious to the charms of co-operative membership.

\section{Co-operative credit and the war}

The war exposed the frailty of the IAOS's credit societies as the provision of co-operative credit collapsed. Organisers viewed the promotion of co-operative 
credit societies since the 1890 s as a crucial means through which small farmers might be immunised against usurious elements within the rural economy. The co-operative credit society was an association of borrowers who came together to provide each other with a collective guarantee and provided a source of funds in lieu of banks and moneylenders. Co-operative credit societies aimed to provide farmers with:

the kind of credit which it is not worth the ordinary banker's while to give - in the first place, because it is asked for an inconvenient length of time - a time which may be altogether uncertain, and which will certainly be too long for occasional lending, and too short for permanent investment. ${ }^{57}$

The IAOS transplanted the Raiffeisen credit society pioneered in Germany to Ireland with the assistance of the British agricultural credit expert Henry Wolff. Raiffeisen co-operative banks were designed as small institutions that operated in limited geographical areas, such as the parish. The most important condition set by Raiffeisen societies for entry into a credit society related to the character of an individual. Someone applying to become a member of a credit society would only succeed if their peers considered them to be reliable and respectable. ${ }^{58}$

In Ireland, the spread of co-operative credit societies proved to be one of the most remarkable phases in the early growth of the movement - at least on paper. The IAOS's role in these societies mirrored the assistance granted to creamery societies as they provided administrative help in the early stages and periodical inspections followed. The first co-operative credit society was founded in 1895 . By 1911, 236 credit societies existed, but only 163 of these furnished annual returns to the IAOS. ${ }^{59}$ The existence of 'skeleton' societies attested to the uneven development of the credit society movement and a reduced number of active societies. While the societies expected to draw upon local funds and savings over time, in the early years these societies were reliant on state loans passed through the DATI in order to add financial liquidity to the rural economy. An investigative committee estimated that in the first seventeen years of the co-operative credit movement a sum of $£ 500,000$ had been loaned to small and medium farmers 'a sum which, even allowing for mere renewals of loans, must have been productive of much benefit to many of the smaller agriculturists, especially in the poorer districts of the country. ${ }^{60}$

The institutional transplant of the German co-operative finance model failed to thrive in Ireland owing to several factors. First, pre-existent forms of rural credit offered too much competition and deprived the rural economy of individuals with a capacity to save. Second, the monitoring aspect of the German model, whereby peer oversight between members forced debtors to repay loans or face ostracism, never took root. This failure on behalf of members to strictly police the credit societies effectively meant that despite their existence on paper, in practice many credit societies failed to perform their primary function. ${ }^{61}$ 
Furthermore, the Raiffeisen model failed to make inroads into the Irish credit market on account of the better-suited and longer-established joint-stock banking institutions. $^{62}$

The Great War exposed the precarious position of co-operative credit in Ireland. At the outbreak of the war the DATI and Congested Districts Board (CDB) withdrew the loan capital they lodged in the credit societies. This action led the IAOS to bemoan the fact that the withdrawal of these loans would have a marked effect on the future of the co-operative credit movement. In cases where but a small business is being done and a joint stock bank is not conveniently accessible or an overdraft obtainable, the business of the society may cease with the repayment of the Board's or the Department's loan'. ${ }^{63}$ Such expectations were borne out over the next four years. The increased prosperity of farmers during the war masked the weakening of this section of the movement. In the more self-reliant credit societies whose books exhibited savings lodged by members business managed to continue. Between March 1918 and March 1919 thirty-nine co-operative societies were wound up, of which thirty-three were credit societies. The IAOS displayed a relaxed attitude to this decline of its credit section as the agricultural boom apparently rendered them unnecessary. Although a return to lower prices for agricultural produce seemed likely in the future the IAOS leadership concluded that:

Of [the co-operative credit society's] utility in past years there is no doubt at all, but the rise in deposits (in many instances due to old borrowers, now comparatively well off, who wish to invest their gains in their societies) and the reduction in the number of loans granted prove that the urgency of the need for cheap credit has diminished. ${ }^{64}$

\section{Co-operation under the wartime state}

Æ emerged as the co-operative movement's most vocal advocate during the second half of the war as he argued for Irish economic self-sufficiency. Horace Plunkett was invited to chair the Irish Convention during 1917 in a failed attempt to find a solution to a political impasse that remained around the proposed implementation of Home Rule after the war. ${ }^{65}$ This left $Æ$ to shape the co-operative movement's response to quickly changing political and economic circumstances. For example, in the immediate aftermath of the Easter Rising, Æ used his position as Irish Homestead editor to address his 'unhappy country'. Despite the unrest caused by the rebellion and the new political uncertainties created in its wake, $Æ$ retained a firm belief that the co-operative movement offered a cause for optimism and a possible avenue for a future consensus between political traditions on the island. 'Because our movement is already national ... and because it alone seems capable of bringing the majority of Irish people into its ranks', he wrote, 'we 
hold that it is the best thing Ireland has at present, and in it is the promise and potency of a happy and prosperous Ireland to be found. ${ }^{66}$ A couple of weeks later, Æ offered another assessment for Irish economics in an uncertain world as he invoked the language of national self-sufficiency. He argued 'that national safety for the people in Ireland demands a complete change in economic policy here ... we must aim at making Ireland self-supporting in respect of food and only sell the surplus' ${ }^{67} \mathrm{~A}$ change in economic policy soon arrived, but not one to Æ's liking.

『 watched how the state in Ireland changed over the course of the war with horror. He viewed the attempt to reorganise the food supply and agriculture in particular, under a new regime of control regulations as an assault on the achievements made by the co-operative movement in previous years. The passage of the Corn Production Act in 1917 'marked a new departure in the agricultural policy of the United Kingdom' that directed farmers to adopt specific methods of agricultural production in pursuit of higher grain yields. ${ }^{68}$ Food production campaigns during 1917-18 encouraged larger yields of vital food staples such as wheat, oats and potatoes. For example, the potato crop for Ireland grew by 27 per cent and annual corn production stood at 545,000 tons more than the respective pre-war figures. ${ }^{69}$ As the war progressed the British government extended its involvement in the politics of food production and distribution. Æ fleshed out his vision of Irish economic self-sufficiency in response to what he viewed as a state structure designed to promote private trading interests. The war demonstrated the continued relevance of the IAOS as an important social actor at a local level, but its influence within official policymaking circles remained negligible. Accordingly, $Æ$ developed a stringent critique of the state system in Ireland based upon regulations and food policies and called for greater autonomy in the aftermath of the war.

Æ's critical theorisation of the co-operative movement's relationship with the state intensified throughout the course of the First World War. Official food policy granted no recognition for the IAOS's war work nor did it prioritise the interests of Irish farmers. Already disillusioned with government departments after the trials with the DATI, and the Development Commission's funding struggles with the DATI, Æ's cynicism of state interference hardened during wartime. The IAOS wielded an important influence over rural Ireland's economic machinery, which it helped to build. However, any hope that food policies might recognise and supplement the work of the IAOS evaporated. Æ's reticence about state interference reflected the influence of anarchist thought upon the poeteconomist's intellectual development. In particular, Prince Kropotkin provided a formative influence over the young $Æ$ as he developed ideas about the promotion of mutual aid and the pursuit of co-operative organisation as a moral imperative. Æ's great ambition for the IAOS remained the creation of a co-operative citizenry 
in Ireland. ${ }^{70}$ His frustration with increased intervention reflected a belief that the state should allow society to grow out of interactions between voluntary organisations. Regulations only impeded such flourishing.

In 1916, Æ published The National Being, in which he outlined his vision of an idealised Irish polity. This book attempted to flesh out the social and economic values best suited to the Irish nation. Æ's concern with the social and economic aspect of the 'Irish Question' marks out The National Being, along with Plunkett's Ireland in the New Century, as exceptional contributions to the literature of the Irish Revival. Like his contemporaries, Æ anticipated the implementation of some form of political independence for Ireland after the war and he therefore made his case for a version of Irish nationhood that included a major role for co-operative societies as centres of social and economic development. Æ wrote in an idiosyncratic style that incorporated his abiding interest in mysticism and he defined the state as 'a physical body prepared for the incarnation of the soul of the race. The body of the national soul may be spiritual or secular, aristocratic or democratic, civil or militarist.' Therefore the type of social arrangement that prevailed would fundamentally shape the character of the type of state to come. Æ viewed the state in Ireland as a manifestation of the country's governmental institutions, and wrote: 'if there is anything in the theory of Irish nationality, we will apply original principles as they are from time to time discovered to be fundamental in Irish character. ${ }^{71}$ The leadership offered by the IAOS as it worked to extend the co-operative principle helped Irish people rediscover one of these fundamental national virtues.

In Ireland, ideas about the state came entwined within discourses around contested claims for political independence, based on physical territory and notions of national identity. For Æ, the nation, and therefore the state, was the summation of the character of its people. Æ believed that the outline of a potential, future Irish state had not been delineated and remained unclear. Despite passionate discussions around self-government, Æ lamented the lack of intellectual effort devoted to the 'speculation over our own character or the nature of the civilization we wished to create for ourselves. Nations, rarely ... start with a complete ideal. ${ }^{72}$ The IAOS represented an important agent in the state-building process as it took the rural subject as its starting point and through its interventions and organisational work strove to remake the Irish population. Over the previous quarter century, $Æ$ argued, 'the co-operative principle has once more laid hold on the imagination of the Irish townsman and the Irish countryman'. The adoption of 'a policy which will enable it to manifest once more ... will create an Irish civilization, which will fit our character as the glove fits the hand'. ${ }^{73}$ With its potential to unite the town and country, co-operation also contained the potential to bind together the Irish nation and produce the type of state $Æ$ believed possible. The IAOS's economic work to reform the farmer amounted to the same thing as defining the nature of the state. 
An Irish form of national economics rested on the principles of co-operation. This belief held by $Æ$ helped to define an emergent nationalist conception of an ideal economy in Ireland and the growth of wartime controls offered the opposite. $\rightleftarrows$ reflected a trend in a country such as India whereby an anti-imperialistic conception of a national economy emerged in response to attempts to integrate regional economies into a wider imperial order. The evolution of national economics in India had its origins in the late nineteenth century and challenged the politicaleconomic imagination that underpinned Britain's attempt to establish an imperial economy. Importantly, an economic critique of British rule provided anti-colonial activists with a basis to discredit British rule. ${ }^{74}$ The experience of wartime controls that hampered co-operative economics provided evidence of a similarly tyrannical economic arrangement ill-suited to Irish needs. Critics saw the imposition of wartime controls over food production as something that served British imperial interests over Irish ones. ${ }^{75}$ For the co-operative movement's leaders, the state frequently obstructed co-operative businesses from achieving their full potential as indicated by their lack of involvement within the food policymaking process.

Irish anti-colonial intellectuals with an interest in outlining a national form of economics paid close attention to the work disseminated by $Æ$. The intellectual engagement by nationalists with co-operative ideas that started with the public dispute between the IAOS and DATI only intensified during the war. The publication of The National Ideal had a profound effect on the Sinn Féin intellectuals, Darrell Figgis and Aodh de Blácam. These two writers tried to conceptualise a social programme for a future Sinn Féin administration that drew heavily upon the economic arguments made by $Æ$. Figgis published his own study of $Æ$ with the revealing subtitle $A$ Study of a Man and a Nation in the same year The National Being appeared. ${ }^{76}$ The next year Figgis published The Gaelic State in the Past and the Future, in which he argued that co-operative societies already provided evidence of an emergent Irish state. ${ }^{77}$ Aodh de Blácam, echoed this position in Towards the Republic, which sought to express the social and political aims of a new Ireland and took for granted 'that the future of Ireland lies in Co-operation no observer of the times can doubt'. De Blácam praised the 'the co-operative work of Mr. George Russell' which he placed alongside the work of the leaders of the 1916 Rising and Arthur Griffith, the founder of Sinn Féin. ${ }^{78}$

The process whereby ideas of Irish nationhood became associated with cooperative principles accelerated as long as the war continued. The British government's agricultural policy during the war fit into two broad stages. Until December 1916, the policy followed a broadly laissez-faire direction which allowed the co-operative movement to work relatively unimpeded. After 1917 a new coalition government under Prime Minister David Lloyd George saw a more interventionist approach to economic policy. ${ }^{79}$ At first $Æ$ hoped that the voluntary efforts coordinated by the IAOS might remain unimpeded by creeping state interference. Expecting 'the State or a State Department to undertake this [agricultural] work 
is to ask a body influenced and often controlled by powerful capitalists, and middle agencies which it should be the role of the ... [IAOS] to eliminate. ${ }^{80}$ The war intensified this position, as the direction of government policy failed to meet the expectations of co-operators.

As the government intervened in food policy, the co-operative movement became frustrated and alienated from the overall policy consultation. In their survey of British co-operation, Fred Hall and William Watkins noted that it was in the protection of the consumer ... that war-time collectivism was seen in its extremest $[s i c]$ forms' ${ }^{81}$ From the perspective of a producers' movement these interventions proved less welcome, which Æ aggressively critiqued as an attempt to stifle the co-operative political economy. The government established the Food Production Department in 1917 with power to organise agricultural production, labour and technology. ${ }^{82}$ The same year's Corn Production Act gave the Department powers to direct resources towards intensified production and output in priority foods such as corn and potatoes. ${ }^{83}$ In Ireland, the practical implementation of these new government regulations fell under the DATI, which introduced the measures that included compulsory tillage orders, minimum wage rates, guaranteed prices for grain and a temporary suspension of land purchase and redistribution. In an example of rare co-ordinated action between the IAOS and government, the Irish Homestead carried DATI circulars and appeals aimed at readers to respond to these demands. For example, one publicity campaign explained that the government order to increase tillage farming would not harm farmers who relied on livestock for their income and identified increased tillage as a way to stimulate milk production: 'More tillage means more men, more cattle, more work, more prosperity. ${ }^{184}$ The same edition's editorial complemented the official message and reminded readers that just as soldiers, doctors and consumers were called upon to do their part in the war effort it is no less the honour of farmers to produce food as plentifully as they can when the nation requires it of them'. ${ }^{85}$

The wartime state represented a new type of tyranny that undermined the co-operative movement's attempt to create a better society. Æ viewed this state with profound mistrust, because we dread its alliance with the meanest and most greedy elements in society, the profiteers and Gombeen men, the class who furnish political parties with funds and who are therefore in a position to affect the policy of State departments'. Under the cover of the war the conflict between co-operators and long-standing economic rivals became an increasingly intense struggle for influence and access to state-controlled resources. In article headed 'The Allies of the State', Æ attacked those who accepted this situation as 'people with the ideas of an infant school who suppose that the State or its officials are always nobly moved or inspired to act solely for the general good'. Rather greater scepticism was required as the 'State allies itself with the party which seems to it economically most powerful ... and this leaning to the economically powerful, 
even when that power is based upon pure greed and ferocious profiteering, has been evident through all the years of the war'. Instead under the cover of war, a new compact was struck in which the

State made a deal with the profiteers early in the war. It said to them ... 'Go you and fleece the people. We will allow you to keep forty per cent of the extra plunder and we will take sixty per cent.' That is exactly what the legislation about excess profits means, that and nothing else. The State at present is the prime profiteer, the profiteer of the profiteers. That is why we fear the future with the State dominating every factor in national life. ${ }^{86}$

Increased state intervention that aimed to stimulate Irish food productivity largely ignored the presence of the co-operative movement. Lord Rhondda was appointed Food Controller in June 1917 and established local committees to engineer the equitable distribution of food, commandeer supplies when required and eventually introduce compulsory rationing. The imposition of controls over which co-operative farmers had no say provoked an angry response from $Æ$ and he used the Irish Homestead to attack Rhondda's agricultural policy. Æ criticised the state's decision to use other 'bodies to undertake new organisation of food production':

We see continual reference to urban councils, district councils, boards of guardians, traders and merchants who are to supervise, procure land, re-allot it, get seeds, fertilisers, implements, and generally to control all this work. We have not seen the slightest official recognition of the existence of farmers' associations and cooperative societies, of which there are well over one thousand in Ireland. ${ }^{87}$

By 1917, the toxic relationship between the two largest agricultural institutions in Ireland led $Æ$ to accuse the DATI of regarding farmers 'as people of no importance in agriculture, their organisations as bodies which need not be considered'. ${ }^{88}$ The DATI refused to acknowledge co-operators as an instrument through which to work and preferred to work with farmers as individuals rather than through corporate entities. According to $Æ$, the DATI mistrusted the IAOS whose 'gigantic business by voluntary associations of farmers is regarded as another instance of [the IAOS's] lack of intelligence because it was built up in disregard of the Department's advice'. ${ }^{89}$

The Ministry of Food's distance from Dublin heightened the sense that Westminster used this ministry to override the interests of Irish farmers. Lord Rhondda appointed Robert Anderson to the Irish section of the Food Control Committee, but the Cork man saw his time there as 'spent in more or less fruitless ferryings over the Irish Sea to attend meetings in London'. ${ }^{90}$ Anderson resigned his position on the committee in December 1917 and the Homestead reported the move as one to be expected as 'self-respecting men cannot remain on a committee whose advice is ignored by those who appointed it'. A more useful 
policy, the article continued, 'would be to have had an Irish Ministry of Food with complete authority in Ireland to act in the interests of the Irish people. How such things can be arranged by a food controller in London we do not know'. ${ }^{1}$

The Ministry of Food and the role played by the Food Controller in setting prices paid to producers attracted Æ's opprobrium. His problem with the food prices set by Lord Rhondda pivoted on the price differentials that existed between Irish produce and comparable goods from other countries that included England. While Kavanagh noted the increased prosperity of farmers during the war, the notion of a satisfied agricultural population becomes more complicated when compared to agricultural producers elsewhere. In anticipation of imminent fixed prices for butter, $Æ$ repeated a rumour that Irish butter would receive around $6 d$. per cwt. less than the same article from New Zealand. The problem with such regulation resided in the fact that Irish butter would be enshrined in a

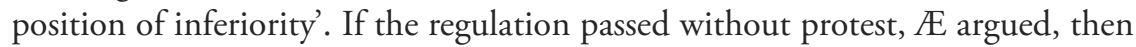
'the market will have hammered into it the idea that Irish butter is in the view of the Government an article inferior in food value to Danish or New Zealand butter'. Furthermore, the effects of regulation would shape long-term impressions that 'will last long after the War'. ${ }^{92}$

In July $1917, Æ$ again wrote on the 'fixing of prices' in which he argued that 'hardly any social problem so thorny ... as food prices' existed and objected to 'the fixing of prices against Irish and in favour of English, Colonial, and foreign interests'. ${ }^{93}$ The sense of injustice filtered down to local co-operatives. Ballycanew Co-operative Society passed a resolution that September objecting to the fact that Irish farmers received less than half the guaranteed price of their English counterparts. The society strongly protested 'against the maximum price of Irish creamery butter fixed by the Food Controller' and demanded 'an immediate advance of $30 \mathrm{~s}$. per cwt., with a further advance to meet the increased cost of production during the winter months'. ${ }^{94}$

At the start of 1918, Æ characterised the government's policies as an effort 'to empty Ireland of its food supplies, to transfer all grain, meat, butter, bacon, etc., possible to the other side, and to leave Ireland largely dependent on the chances of imported food'. ${ }^{5}$ By June he wrote: 'Irishmen are threatened not only by the submarines which lie around their coasts, but by the action of the economic machinery which has grown up in their country. ${ }^{96}$ The impact of regulation led one correspondent to the Homestead to write that it is now manifest to the Irish farmer that the Food Controller is out to make a Sinn Feiner of him ... Every new order the Food Controller makes confirms the belief that the Irish farmer must depend upon himself and not trust his big brother across the channel. ${ }^{97}$ The Food Controller provided a bogeyman for those who drew up Sinn Féin's economic thinking. In 1920, Darrell Figgis cited the 'English Food Controller' whose preferential treatment of English over Irish farmers gave grounds for political independence. Food controls served the interests of English manufacturers 
and their introduction revealed that 'war was only an excuse for national avarice and imperial depredation'. ${ }^{98}$

Under Æ's wartime direction the Homestead argued that farmers needed to exercise greater economic autonomy as the most effective way to guard against state tyranny. The fear that wartime controls might continue indefinitely provided a source of concern. In the final months of the war, the co-operative movement again attempted to rally members around its founding principles. By this point, $Æ$ urged farmers that 'if you want political attention create economic organisations. Control trade, and you will be recognised by the state.' If farmers allowed their 'business [to] be controlled by others than yourselves ... the state will listen to those who control your trade, not to you. ${ }^{99}$

By the war's end the dividing line between economic and political independence grew indistinct, as all threads of the Irish question became entwined. The IAOS ended the war having provided stability after 'a crucial test during the last five years':

Its steady growth and remarkably rapid development in new directions - some of a far more ambitious character than any previously undertaken by the organised farmers - afford yet another proof of the superiority of co-operative organisation under conditions of stress. The societies have not only held together, but have also improved their buildings and equipment as well as their business methods ... members, too, have come to realise what their movement means to them, what it has accomplished and what it may yet accomplish. Co-operation is now a reality to many to whom it had hitherto meant little more than a trade term. ${ }^{100}$

The movement's overall progress up to 1918 indicated that co-operative societies maintained their popularity. Farmers looked towards the IAOS as a familiar source of authority in a period of social and political uncertainty. The new types of trade taken up by co-operative societies showed that the war incentivised a greater diversity of co-operative activities. After 1918 the IAOS received greater legal freedom with regard to its organisational work, as a reward. The Development Commissioners recommended that restrictions placed on the IAOS's involvement in other forms of co-operation beyond production should be loosened and there should be an end to the DATI's policy of non-controversial co-operation. This coincided with T.W. Russell's retirement from public life in 1918, which suggested an opportunity for a new relationship between the IAOS and the DATI. The emergence of a new type of diverse co-operative society that engaged in both agricultural production and limited retail by the end of the war led Horace Plunkett to express hope that the movement might now 'make much more rapid progress than hitherto in extending the benefits of co-operation to those who need them most'. ${ }^{101}$

If the war represented a trial of co-operative organisation, then, according to its leaders, the Irish movement had passed. Whatever the ultimate political 
settlement for Ireland, the will to play a prominent role in shaping the economic arrangement of an Irish nation-state was central to co-operative thinking. The ability of the co-operative movement to influence a future Irish state developed in unexpected ways after 1918. The failure to find an accommodation with the DATI combined with growing alienation from the government, moved the co-operative movement into a position whereby it became a hostile critic of the state as it operated in Ireland. This pushed the movement into a closer accommodation with an unexpected force - radical nationalism.

\section{Notes}

1 IAOS, Annual Report, 1919, p. 5.

2 Charles Townshend, Easter 1916: The Irish Rebellion (London: Penguin, 2006).

3 Michael Laffan, The Resurrection of Ireland: The Sinn Féin Party, 1916-1923 (Cambridge: Cambridge University Press, 1999), 164.

4 Diarmaid Ferriter, The Transformation of Ireland, 1900-2000 (London: Profile Books, 2004), 172-173.

5 Patrick Kavanagh, The Green Fool (London: Penguin, 2001), 58.

6 Stephen Gwynn, Ireland (London: Ernest Benn, 1924), 73.

7 Jonathan Bell and Mervyn Watson, A History of Irish Farming, 1750-1950 (Dublin: Four Courts Press, 2009), 247.

8 F.S.L. Lyons, Ireland Since the Famine (London: Fontana Press, 1975), 369.

9 R.A. Anderson, With Horace Plunkett in Ireland (London: Macmillan and Co.,1935), 192, 196-197.

10 Fran Brearton, The Great War in Irish Poetry: WB Yeats to Michael Longley (Oxford: Oxford University Press, 2000), 7.

11 Lionel Smith-Gordon, 'Agricultural Organisation in Ireland', Economic Journal, 27.107 (1917), 355-363 (p. 355).

12 IAOS, Annual Report, 1914, 7.

13 Margaret Digby, Horace Plunkett: An Anglo-American Irishman (Oxford: Basil Blackwell, 1935), 207.

14 IAOS, Annual Report, 1915, 42.

15 IAOS, Annual Report, 1914,7.

16 Alan S. Milward, The Economic Effects of the Two World Wars on Britain (London: Macmillan Press Ltd, 1972), 50.

17 IAOS, Annual Report, 1915, 5.

18 J.R. Campbell, 'The War and Irish Agriculture', Department of Agriculture and Technical Instruction Journal, 15.1 (1914), 10-19 (pp. 12-15); IAOS, Annual Report, 1915, 7.

19 Peter Gatrell, Russia's First World War: A Social and Economic History (Harlow: Pearson Longman, 2005), 46.

20 George W. Russell, 'The Problem of Rural Life', Irish Review 1.8 (1911), 365-372 (p. 368).

21 Lionel Smith-Gordon and Cruise O'Brien, Ireland's Food in War Time (Dublin: Co-operative Reference Library, 1914), 44. 
22 T. O’Donovan, Abbeydorney to Anderson, Dublin 14 August 1914, and Anderson to O'Donovan, 15 August 1914, NAI 1088/2/2.

23 HCPP [Cd. 8016], Department of Agriculture and Technical Instruction for Ireland. Report of the Departmental Committee on Food Production in Ireland (1914-1916), 4-6.

24 Wibberley published a work on intensification of tillage farming in 1917. T. Wibberley, Farming on Factory Lines: Continuous Cropping for the Large Farmer (London: C. Arthur Pearson Ltd, 1917).

25 HCPP [Cd. 8016], Report of the Departmental Committee on Food Production in Ireland (1914-16), 11-12.

26 IAOS, Annual Report, 1915, 7-8.

27 R.A. Anderson to C.C. Riddall, 25 August 1916, NAI 1088/2/3.

28 James Meenan, The Irish Economy Since 1922 (Liverpool: Liverpool University Press, 1970), 302-303.

29 Edward A. Fitzpatrick, McCarthy of Wisconsin (New York: Columbia University Press, 1944).

30 Horace Plunkett, A Country Life Institute: A Suggested Irish-American Contribution to Rural Progress (Dublin: Plunkett House, 1909), 25.

31 Lionel Smith-Gordon and Cruise O'Brien, Co-operation in Ireland (Manchester: Co-operative Union Limited, 1921), 26.

32 These reports included D. Houston, The Milk Supply of Dublin: Report of a Bacteriological Investigation of the City of Dublin Milk Supply (Dublin: The Co-operative Reference Library, 1918); Cruise O'Brien, Co-operative Mills and Bakeries, Series: Miscellaneous Publications No. 2 (Dublin: Co-operative Reference Library, 1918); Smith-Gordon and O'Brien, Ireland's Food.

33 O’Brien, Co-operative Mills, 1.

34 Smith-Gordon and O'Brien, Ireland's Food, 39.

35 Anderson, With Horace Plunkett, 194.

36 Patrick Bolger, The Irish Co-operative Movement: Its History and Development (Dublin: Institute of Public Administration, 1977), 208.

37 'A Commendable Enterprise', Sligo Independent, 29 April 1916; Notes for speech on Co-operative Mill for Drumcliffe by Josslyn Gore-Booth, undated, c.1916, PRONI, D4131/M/11A.

38 Anderson, With Horace Plunkett, 197.

39 John O'Leary, IAOS Creamery Organiser's Report for Abbeydorney, 7 January 1915, NAI $1088 / 2 / 3$.

40 T. O’Donovan, Abbeydorney to R.A. Anderson, Dublin, 22 January 1915, NAI $1088 / 2 / 3$.

41 J. O’Leary's Creamery Report, Abbeydorney, 11 September 1916, NAI 1088/2/3.

42 C.C. Riddall's Report on Visit [6 August 1916], 24 August 1916, NAI 1088/2/3.

43 Robert Anderson to C.C. Riddall, 25 August 1916, NAI 1088/2/3.

44 Robert Anderson to Director General of Munitions Supply, Westminster, 7 February 1917, NAI 1088/2/3.

45 R.A. Anderson, 'The IAOS and the Food Problem', Studies, 6.21 (1917), 8-14 (p. 11). 
46 Mary E. Daly, The First Department: A History of the Department of Agriculture (Dublin: Institute of public Administration, 2002), 58-60.

47 'Irish Cheese' [advertisement], Irish Homestead, 17 August 1918, 553.

48 Thomas de Lacy, Newtownsandes to C.C. Riddall, Dublin, 27 February 1918, NAI 1088/751/6.

49 IAOS, Annual Report, 1909, 10.

50 For example see J Byrne, Ballymacelligott to James Fant, 31 July 1922, NAI/1088/70/1.

51 'Co-operative Conferences', Anglo-Celt, 3 February 1917, 10.

52 IAOS, Annual Report, 1919, 9.

53 Daly, The First Department.

54 IAOS, Annual Report, 1919, 9.

55 'Economic Independence', Irish Homestead, 15 June 1918, 397-398.

56 IAOS, Annual Report, 1919, 19.

57 Henry W. Wolff, People's Banks: A Record of Social and Economic Success (London: P.S. King and Son, 1896, 2nd edn [originally published 1893]), 68.

58 Anthony P. Quinn, Credit Unions in Ireland (Dublin: Oak Tree Press, 1994), 10-11.

59 HCPP [Cd. 7375], DATI, Report of the Departmental Committee on Agricultural Credit in Ireland (1914), 128.

60 HCPP [Cd. 7375], Report ... on Agricultural Credit in Ireland (1914), 129-130.

61 Timothy Guinnane, 'A Failed Institutional Transplant: Raiffeisen's Credit Cooperatives in Ireland, 1894-1914', Explorations in Economic History, 31 (1994), 38-61.

62 Eoin McLaughlin, 'Competing Forms of Co-operation?: Land League, Land War and Co-operation in Ireland, 1879 to 1914', Agricultural History Review, 63.1 (2015), 81-112.

63 IAOS, Annual Report, 1915, 17.

64 IAOS, Annual Report, 1919, 13-14.

65 R.B. McDowell, The Irish Convention, 1917-18 (London: Routledge \& Kegan Paul, 1970).

66 'The Hope that Remains', Irish Homestead, 29 April, 6 and 13 1916, 285-286.

67 'Lessons from the War', Irish Homestead, 10 June 1916, 353-354.

68 Department of Agriculture and Technical Instruction for Ireland, Eighteenth Annual General Report of the Department, 1917-18 (Dublin: His Majesty's Stationery Office 1919), 12.

69 Margaret L. Barnet, British Food Policy during the First World War (London: George Allen \& Unwin, 1985), 193-208.

70 Nicholas Allen, George Russell (Æ) and the New Ireland, 1905-30 (Dublin: Four Courts Press, 2003), 40-43.

71 George William Russell, The National Being: Some Thoughts on an Irish Polity (Dublin: Maunsel \& Co., 1916), 2.

72 Russell, The National Being, 3.

73 Russell, The National Being, 125-126.

74 Manu Goswami, Producing India: From Colonial Economy to National Space (Chicago: University of Chicago Press, 2004), 279-280.

75 Ian Miller, Reforming Food in Post-Famine Ireland: Medicine, Science and Improvement, 1845-1922 (Manchester: Manchester University Press, 2014), 192. 
76 Darrell Figgis, George W. Russell: A Study of a Man and a Nation (New York: Dodd, Mead and Company, 1916).

77 Darrell Figgis, The Gaelic State in the Past and Future or 'The Crown of the Nation' (Dublin: Maunsel \& Co. Ltd, 1917), 74.

78 Aodh de Blácam, Towards the Republic: A Study of New Ireland's Social and Political Aims (Dublin: T. Kiersey, 1918), 26, 119.

79 P.E. Dewey, British Agriculture in the First World War (London: Routledge, 1989), 23.

80 Russell, The National Being, 53.

81 F. Hall and W.P. Watkins, Co-operation: A Survey of the History, Principles, and Organisation of the Co-operative Movement in Great Britain and Ireland (Manchester: Co-operative Union, 1937), 197.

82 Dewey, British Agriculture, 91-93.

83 Daly, The First Department, 58-61.

84 'The Country's Food Supply, 1917' [advertisement], Irish Homestead, 10 February 1917, 97.

85 'Agriculture on its Trial', Irish Homestead, 10 February 1917, 85-86.

86 'The Allies of the State', Irish Homestead, 20 January 1917, 34-35.

87 'The New Guides for Agriculture', Irish Homestead, 13 January 1917, 17-18.

88 'The New Guides for Agriculture', Irish Homestead, 13 January 1917, 17-18.

89 'The New Guides for Agriculture', Irish Homestead, 13 January 1917, 17-18.

90 Anderson, With Horace Plunkett, 194.

91 'The Food Control Committee', Irish Homestead, 29 December 1917, 950-951.

92 'The Fixing of Prices' Irish Homestead, 24 March 1917, 205-206.

93 'The Fixing of Prices', Irish Homestead, 14 July 1917, 521-522.

94 'Among the Societies: Ballycanew C.A. \& D.S.', Irish Homestead, 29 September $1917,734$.

95 'Killing Food Production', Irish Homestead, 19 January 1918, 34.

96 George Russell (Æ), 'The Self-Supporting Community’, Studies, 7.26 (1918), 301-306 (p. 301).

97 Farmer, 'A Policy for Irish Farmers', Irish Homestead, 29 September 1917, 730.

98 Darrell Figgis, The Economic Case for Independence (Dublin: Maunsel \& Co., 1920), vi.

99 'The State and Organisation', Irish Homestead, 20 July 1918, 477-478.

100 IAOS, Annual Report, 1919, 5.

101 IAOS, Annual Report, 1919, 38. 